\title{
A novel intramandibular gland in the ant Brachyponera sennaarensis
}

Johan Billen ${ }^{1}$ and Mohammed Al-Khalifa ${ }^{2}$

1 Zoological Institute, University of Leuven, Naamsestraat 59, box 2466, B-3000 Leuven, Belgium. E-mail: johan.billen@bio.kuleuven.be

2 Department of Zoology, College of Science, P.O. Box 2455, King Saud University, Riyadh 11451 (Saudi Arabia). E-mail: mkhalifa@ksu.edu.sa

Keywords: morphology, ultrastructure, intramandibular gland, Brachyponera sennaarensis.

Running title: novel intramandibular gland in Brachyponera sennaarensis

\section{Contact address:}

Johan Billen, KU Leuven, Zoological Institute, Naamsestraat 59, box 2466, B-3000 Leuven, Belgium

Tel : $\quad$ (32) 16323975

Fax : (32) 16324575

E-mail: johan.billen@bio.kuleuven.be 
One of the diagnostic characters of the ponerine ant genus Brachyponera is the presence of a mandibular pit near the insertion of the mandible. This paper describes the morphology and ultrastructure of a novel intramandibular gland in B. sennaarensis, that is associated with this pit. The gland appears as a conspicuous epithelium that lines the invaginated cuticle of the pit, and that extends distally into the upper and lower outer wall of the mandible. This novel 'mandibular pit gland' occurs in both workers and queens, but is absent in males. At the ultrastructural level, the cytoplasm of the cylindrical secretory cells is dominated by a well-developed smooth endoplasmic reticulum. Apical microvilli and clear transcuticular channels allow secretion to reach the mandibular surface. Although the function of this novel gland is not yet known, the cytoplasmic organization is in line with the production of a pheromonal secretion. 


\section{INTRODUCTION}

The samsum ant Brachyponera (formerly Pachycondyla) sennaarensis is common in the Eastern African savannas, but has recently expanded more and more into the Middle East (Paknia et al., 2006; Al-Khalifa et al., 2010; Wetterer, 2013). As the ants search for humidity to nest in this mainly arid region, they inevitably come in contact with humans. Because of their very painful sting that may even cause anaphylactic shock (Al-Shawan et al., 2006; Al-Anazi et al., 2009), B. sennaarensis has become a serious pest (Al-Khalifa et al., 2015). Its pest status inspired us to study the general exocrine system of this species, of which a first part already described the pro- and postpharyngeal glands (Billen and Al-Khalifa, 2015).

Brachyponera ants (together with Euponera and most Cryptopone species) are characterized by the presence of a conspicuous mandibular pit near the mandibular insertion. This diagnostic character also led to the recent genus re-assignment of the samsum ant from Pachycondyla to Brachyponera (Schmidt and Shattuck, 2014). The function of this mandibular pit is not known, but we discovered a large and hitherto unknown exocrine gland underneath this structure, that we here describe.

\section{MATERIAL AND METHODS}

Workers, alate queens and males of Brachyponera sennaarensis were collected from a large colony nesting between the root system of a date palm tree at Naa'm, Huata bani Tamim region in the south of Riyadh, Saudi Arabia. The distal tip of the mandibles was cut off to allow optimal penetration of the various chemicals into both the distal tip and the proximal region of the mandible during tissue processing. Both the mandibular tips and heads with tipless mandibles were fixed in cold $2 \%$ glutaraldehyde, buffered at pH 7.3 with $50 \mathrm{mM}$ sodium cacodylate and $150 \mathrm{mM}$ saccharose. Postfixation was done in $2 \%$ osmium tetroxide in the same buffer. After dehydration in a graded acetone series, tissues were embedded in Araldite and sectioned with a Leica EM UC6 ultramicrotome. Semithin sections of $1 \mu \mathrm{m}$ were stained with methylene blue and thionin and viewed with an Olympus BX-51 microscope. Thin sections of $70 \mathrm{~nm}$ were double stained with lead citrate and uranyl acetate and examined with a Zeiss EM900 electron microscope. For SEM, heads were mounted on stubs, gold coated, and viewed in a JEOL JSM-6360 scanning microscope. 


\section{RESULTS}

The mandibles of both workers and queens of Brachyponera sennaarensis are characterized by a conspicuous lateral pit near their articulation with the head capsule (Fig. 1). The pit has a diameter of approximately $20 \mu \mathrm{m}$, and has a slightly wrinkled lining (Figs 1C,D). Sections through the mandibles revealed the occurrence of a prominent epithelial gland underneath the pit cuticle. The glandular epithelium extends along the upper and lower mandibular surface, and thus forms a large exocrine structure along the outer part of the mandibles (Figs 2A,B). The dorsal part of the gland lines approximately the proximal half of the upper mandible, while the ventral part more or less lines the middle third of the lower mandible part (Fig. 1A). The general anatomical as well as ultrastuctural characteristics of the three parts (pit epithelium, dorsal epithelium and ventral epithelium) are the same, which makes us conclude they are part of the same major exocrine structure.

The glandular epithelium has a thickness of 40-50 $\mu \mathrm{m}$ and consists of cylindrical class-1 cells following the standard classification of Noirot and Quennedey (1974). The rounded to oval nuclei have a central location, and measure 8-10 $\mu \mathrm{m}$. The cuticle that overlays the glandular epithelium at the light microscopy level shows cross striations (Figs 2A,B) that with electron microscopy appear as irregularly shaped transcuticular channels that open at the surface through small pores (Figs 3A,B,D). Scanning microscopy at high magnification shows an abundance of the corresponding pores, that have a slit-like appearance with a width of approximately $0.1 \mu \mathrm{m}$ and a length of 0.2-0.5 $\mu \mathrm{m}$ (Fig. 3C).

The apical cell membrane of the glandular cells shows a regular pattern of microvilli that have a length of 1-2 $\mu \mathrm{m}$ and a diameter of $0.1 \mu \mathrm{m}$ (Figs 3D,E). The most dominant organelle fraction in the cytoplasm is formed by smooth endoplasmic reticulum (Figs 3D-G), of which extensions penetrate into the core of the microvilli (Fig. 3E). Further cytoplasmic elements are apically occurring lamellar inclusions (Fig. 3D), mitochondria and a clear Golgi apparatus (Fig. 3F). Small areas with free ribosomes are found near the nuclei, while the cytoplasm in the subnuclear region contains a local accumulation of granular endoplasmic reticulum (Fig. 3H). The lateral cell membranes show desmosomes and septate junctions in the upper region (Fig. 3E), while the membranes of the two adjoining cells locally distend to form round intercellular spaces with a diameter of $0.25-0.5 \mu \mathrm{m}$ (Figs 3D,E). In the lower regions of the cell, intercellular 
junctions occur as two parallel and tortuous membranes without any special differentiations. The basal cell membrane rests on a very thin basement membrane, and is thrown into irregular short basal invaginations (Fig. 31). Tracheoles with a diameter of $0.5 \mu \mathrm{m}$ penetrate in the lower part of the cells (Figs $3 \mathrm{H}, \mathrm{I}$ ).

We did not find any class 3 intramandibular gland cells. Males have very short mandibles, and do not have mandibular pits, nor any of the glandular structures as described in workers and queens.

\section{DISCUSSION}

Social insects are well known for the astonishing development of their exocrine system. At present, 149 different glands have been described for all social insect groups together, of which 84 have been reported for the ants (Billen and Šobotník, 2015). Our description of the novel mandibular pit gland in the present paper adds yet another gland to the glandular repertoire of ants and brings it to 85. In spite of the big variety of exocrine glands, their anatomical organization allows a quite simple classification as either epithelial class 1 or class 3 glands, that are formed by one or more bicellular units (Noirot and Quennedey, 1974; class 2 gland cells have later been homologized with oenocytes: Noirot and Quennedey, 1991).

Nedel (1960) was the first to notice intramandibular gland cells of class 3 inside the mandibles of stingless bees and bumblebees. The first report of an intramandibular gland in ants was provided by Schoeters and Billen (1994). This paper gives a survey of a class 3 intramandibular gland in 45 ant species representing the major subfamilies. Several follow-up studies reported on the presence of this common class 3 gland in ants (Polyergus rufescens: Grasso et al., 2004; Atta sexdens rubropilosa: Amaral and Caetano, 2006; several ponerine species: Martins and Serrão, 2011; Martins et al., 2013, 2015a,b; Myrmoteras iriodum: Billen et al., 2015; Aneuretus simoni: Billen and Verbesselt, 2016). In spite of these numerous studies, the function of the class 3 intramandibular gland remains unknown. The only case in which the function could be demonstrated is in Oecophylla longinoda weaver ants, that use the gland for substrate marking (Roux et al., 2010). A special kind of intramandibular gland is found in the rare agroecomyrmecine species Tatuidris tatusia, in which the ducts from the numerous class 3 cells come together to open through a single ventral sieveplate at the proximal inner side of each mandible (Billen and Delsinne, 2014). 
The variation of intramandibular glands becomes even more apparent as also epithelial glands of class 1 can be found. This was first described in stingless bees by Cruz-Landim (1963) and further explored for other stingless bees and bumblebees (Costa-Leonardo, 1978). Epithelial intramandibular glands were then also found in ants: Pyramica (now Strumigenys) membranifera workers have an epithelial gland at the inner side of their mandibles (Billen and Espadaler, 2002), which is a position that may indicate a function related to food processing. Protanilla wallacei workers and queens have a ventrally situated epithelial gland in the proximal part of their mandibles, that because of its proximity to the mouth may have a trophic function (Billen et al., 2013). Also leaf-cutting ants and several ponerine species have been reported to contain epithelial intramandibular glands (Amaral and Caetano, 2006; Martins and Serrão, 2011, Martins et al., 2013, 2015a,b). In Attini, Martins and Serrão (2011) and Martins et al. (2015a) even describe intramandibular glands formed by epithelial cells surrounding a reservoir space, although the suggestive drawings are not confirmed by convincing histological sections; to our understanding, the microscopy images rather look like sensillar structures. The cylindrical epithelial gland, as described in Pachycondyla (now Neoponera) verenae (Martins et al., 2013) and other Ponerini (Martins and Serrão, 2011) somehow reminds of the extended part of the mandibular pit gland that we here describe for Brachyponera sennaarensis. As these other ponerine species do not have a mandibular pit, however, we consider the mandibular pit gland of $B$. sennaarensis a novel intramandibular gland in ants.

The prominent mandibular pit in Brachyponera sennaarensis was first noticed by Mayr (1901). Brown (1963) mentions for many Ponerini ants about the dorsolaterally occurring mandibular pit as well as an oblique dorsal mandibular groove, which he considers as non-homologous structures. While he suggests that the groove may play a role in the distribution of mandibular gland secretion (Brown, 1963), he does not mention any functional significance for the mandibular pit. Our finding of its association with a large exocrine gland may be a first step in understanding its function. The utrastructural features of surface-increasing basal invaginations, apical microvilli, transcuticular channels and surface pores all illustrate the characteristics of an active glandular tissue (Noirot and Quennedey, 1974; Billen and Morgan, 1998). As the gland mainly lines the outer lateral surface of the mandibles, a role in digestion or food processing can probably be excluded. The cytoplasmic composition with smooth endoplasmic reticulum as the main constituent besides the Golgi apparatus, numerous 
mitochondria and lamellar inclusions clearly indicates that the mandibular pit gland produces a non-proteinaceous and therefore possibly pheromonal secretion. The continuation of SER-tubules into the core of the microvilli provides an extra mechanism that ensures an optimal secretion process (Billen and Morgan, 1998). The pit structure may act as a temporary storage space for secretion, and forms a challenge for chemical exploration using microcapillaries or SPME-analysis. Although $B$. sennaarensis is a species with solitary foraging behaviour, known interactions among workers include cooperation in grain transport (Levieux and Diomande, 1978) as well as recruitment using tandem running during nest moving and a chemical marking of the nest entrance (Lachaud and Dejean, 1994). It remains to be checked whether any of these or other behaviours may be directed by secretions from the mandibular pit gland. We hope the structural characteristics reported here may form a basis to perform chemical and behavioural analyses of the secretory products in order to unravel the functional significance of this novel mandibular pit gland.

\section{ACKNOWLEDGMENTS}

We are very grateful to An Vandoren and Alex Vrijdaghs for their assistance in section preparation and scanning microscopy. This study was funded through the research group project $N^{\circ} 340$ from the Deanship of Scientific Research at King Saud University.

\section{REFERENCES}

Al-Anazi M, Al-Ashahrani M, Al-Salamah M (2009) Black ant stings caused by Pachycondyla sennaarensis: a significant health hazard. Annls Saudi Med 29:207211

Al-Khalifa MS, Ahmed AM, Mashaly AMA, Al-Mekhalfi FA, Khalil G, Siddiqui MI, Ali MF (2010) Studies on the distribution of Pachycondyla sennaarensis (Hymenoptera: Formicidae: Ponerinae) in Saudi Arabia. 1. Ar-Riyadh Region. Pakistan J Zool 42:707-713

Al-Khalifa MS, Mashaly AMA, Siddiqui MI and Al-Mekhlafi FA (2015) Samsum ant, Brachyponera sennaarensis (Formicidae: Ponerinae): Distribution and abundance in Saudi Arabia. Saudi J Biol Sci 22:575-579

Al-Shawan M, Al-Khenaizan S, Al-Khalifa MS (2006) Black (samsum) ant induced anaphylaxis in Saudi Arabia. Saudi Med J 27: 1761-1763 
Amaral JB, Caetano FH (2006) The intramandibular gland of leaf-cutting ants (Atta sexdens rubropilosa Forel 1908). Micron 37:154-160

Billen J, Al-Khalifa M (2015) Morphology and ultrastructure of the pro- and postpharyngeal glands in workers of Brachyponera sennaarensis. Sociobiology 62:270-275

Billen J, Delsinne T (2014) A novel intramandibular gland in the ant Tatuidris tatusia (Hymenoptera: Formicidae). Myrmecol News 19:61-64

Billen J, Espadaler X (2002) A novel epithelial intramandibular gland in the ant Pyramica membranifera (Hymenoptera, Formicidae). Belg J Zool 132:175-176

Billen J, Morgan ED (1998) Pheromone communication in social insects - sources and secretions. In: Vander Meer RK, Breed MD, Winston ML and Espelie KE (eds) Pheromone Communication in Social Insects: Ants, Wasps, Bees, and Termites, Westview Press, Boulder, Oxford, pp 3-33

Billen J, Šobotník J (2015) Insect exocrine glands. Arthropod Struct Dev 44:399-400

Billen J, Verbesselt S (2016) The intramandibular gland of Aneuretus simoni (Formicidae, Aneuretinae). Asian Myrmecol 8: in press

Billen J, Bauweleers E, Hashim R, Ito F (2013) Survey of the exocrine system in Protanilla wallacei (Hymenoptera, Formicidae). Arthropod Struct Dev 42:173-183

Billen J, Mandonx T, Hashim R, Ito F (2015) Exocrine glands of the ant Myrmoteras iriodum. Entomol Sci 18:167-173

Brown WL Jr (1963) Characters and synonymies among the genera of ants. Part III. Some members of the tribe Ponerini (Ponerinae, Formicidae). Breviora 190:1-10

Costa-Leonardo AM (1978) Glândulas intramandibulares em abelhas sociais. Cienc Cult 30:835-838

Cruz Landim C. (1963) Evaluation of the wax and scent glands in the Apinae (Hymenoptera: Apidae). J NY Entomol Soc 21:2-13

Grasso DA, Romani R, Castracani C, Visicchio R, Mori A, Isidoro N, Le Moli F (2004) Mandible associated glands in queens of the slave-making ant Polyergus rufescens (Hymenoptera, Formicidae). Insect Soc 51:74-80

Lachaud JP, Dejean A (1994) Predatory behavior of a seed-eating ant: Brachyponera senaarensis. Entomol Exp Appl 72:145-155

Levieux J, Diomande T (1978) La nutrition des fourmis granivores. II. Cycle d'activité et régime alimentaire de Brachyponera senaarensis (Mayr) (Hymenoptera, Formicidae). Insect Soc 25:187-196 
Martins LCB, Serrão JE (2011) Morphology and histochemistry of the intramandibular glands in Attini and Ponerini (Hymenoptera, Formicidae) species. Microsc Res Tech 74:763-771

Martins LCB, Delabie JHC, Zanuncio JC, Serrão JE (2013) Post-embryonic development of intramandibular glands in Pachycondyla verenae (Forel) (Hymenoptera: Formicidae) workers. Sociobiology 60:154-161

Martins LC, Della Lucia TMC, Gonçalves WG, Delabie JH, Zanuncio JC, Serrão JE (2015a) Intramandibular glands in different castes of leaf-cutting ant, Atta laevigata (Fr. Smith, 1858) (Formicidae: Attini). Microsc Res Tech 78:603-612

Martins LCB, do Nascimento FS, Campos MCG, Lima ER, Zanuncio JC, Serrão JE (2015b) Chemical composition of the intramandibular glands of the ant Neoponera villosa (Fabricius, 1804) (Hymenoptera: Ponerinae). Chemoecology 25:25-31

Mayr G (1901) Südafrikanische Formiciden, gesammelt von Dr. Hans Brauns. Ann Naturhist Hofmus Wien 16:1-30

Nedel JO (1960) Morphologie und Physiologie der Mandibeldrüse einiger Bienen-Arten (Apidae). Z Morph Ökol Tiere 49:139-183

Noirot C, Quennedey A (1974) Fine structure of insect epidermal glands. Annu Rev Entomol 19:61-80

Noirot C, Quennedey A (1991) Glands, gland cells, glandular units: some comments on terminology and classification. Annls Soc entomol Fr (NS) 27:123-128

Paknia O (2006) Distribution of the introduced ponerine ant Pachycondyla sennaarensis (Hymenoptera: Formicidae) in Iran. Myrmecol Nachr 8:235-238

Roux O, Billen J, Orivel J, Dejean A (2010) An overlooked mandibular-rubbing behavior used during recruitment by the African weaver ant, Oecophylla longinoda. PLoS ONE 5:e8957

Schmidt CA, Shattuck SO (2014) The higher classification of the ant subfamily Ponerinae (Hymenoptera: Formicidae), with a review of ponerine ecology and behavior. Zootaxa 3817:1-242

Schoeters E, Billen J (1994) The intramandibular gland, a novel exocrine structure in ants (Insecta, Hymenoptera). Zoomorphology 114:125-131

Wetterer JK (2013) Geographical spread of the samsum or sword ant, Pachycondyla (Brachyponera) sennaarensis (Hymenoptera: Formicidae). Myrmecol News 18:1318 

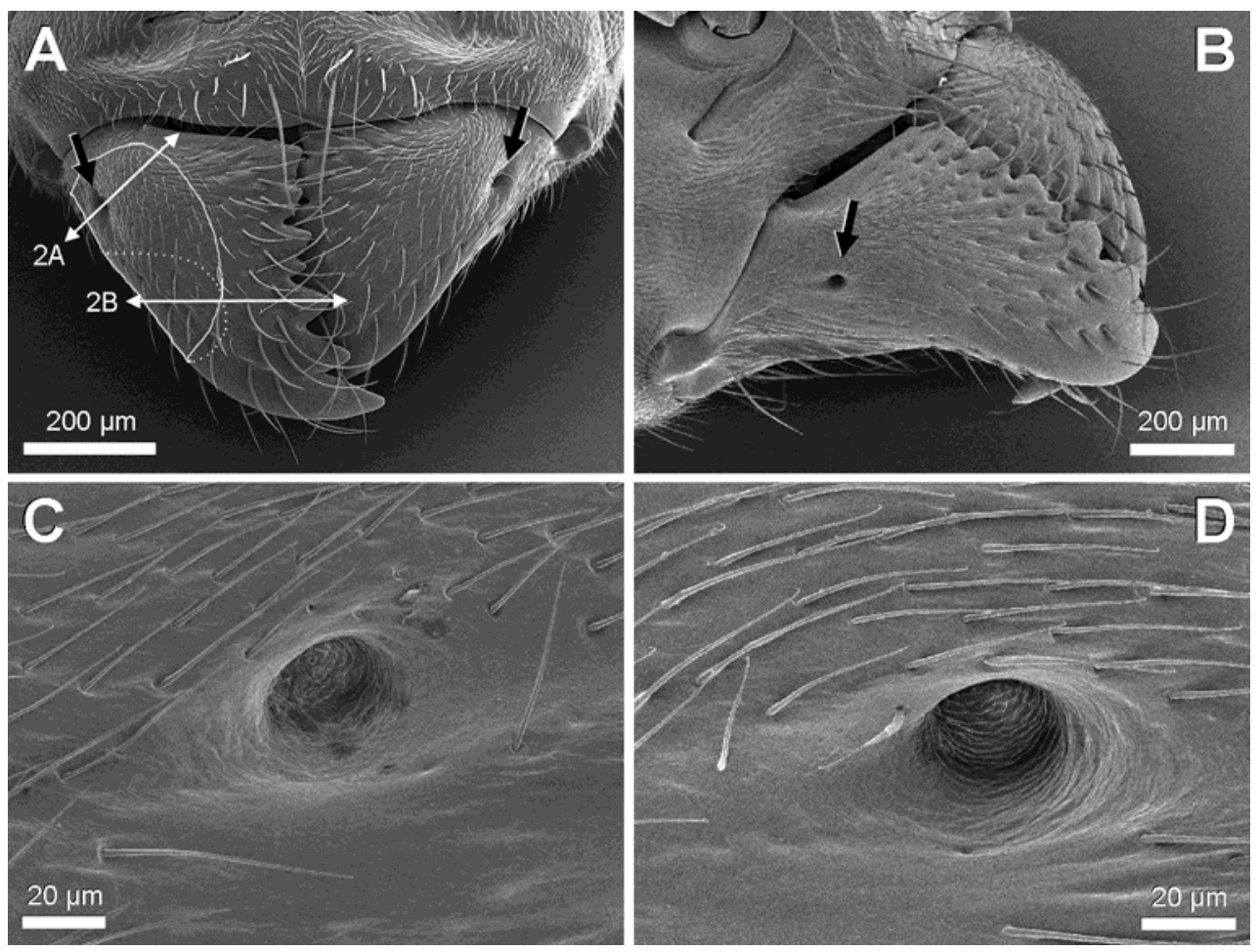

Fig. 1. Scanning micrographs of the mandibles and details of the mandibular pit (black arrows) in $B$. sennaarensis worker $(\mathbf{A}, \mathbf{C})$ and queen $(\mathbf{B}, \mathbf{D})$. In $(A)$, the white line indicates the extent of the intramandibular gland epithelium underneath the dorsal mandibular surface, the dotted white line shows its extent underneath the ventral mandibular surface. The double white arrows indicate the orientation of the transverse sections as shown in figures $2 \mathrm{~A}$ and $2 \mathrm{~B}$. 


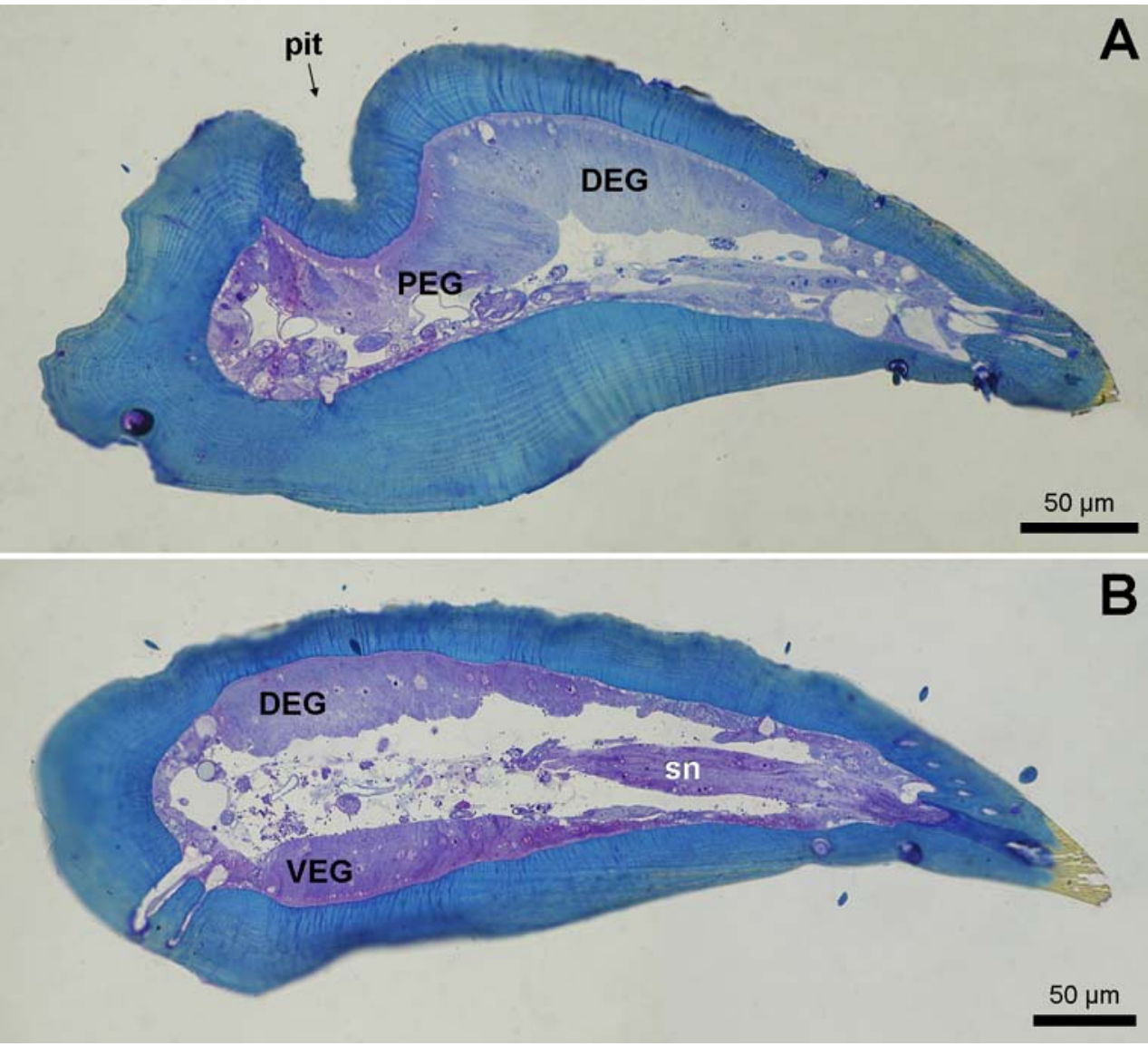

Fig. 2. Transverse semithin sections through the mandibular pit region of a queen (A) and through the more distal mandibular region of a worker (B). DEG: dorsal epithelial gland, PEG: pit epithelial gland, sn: sensillar nerve, VEG: ventral epithelial gland. 

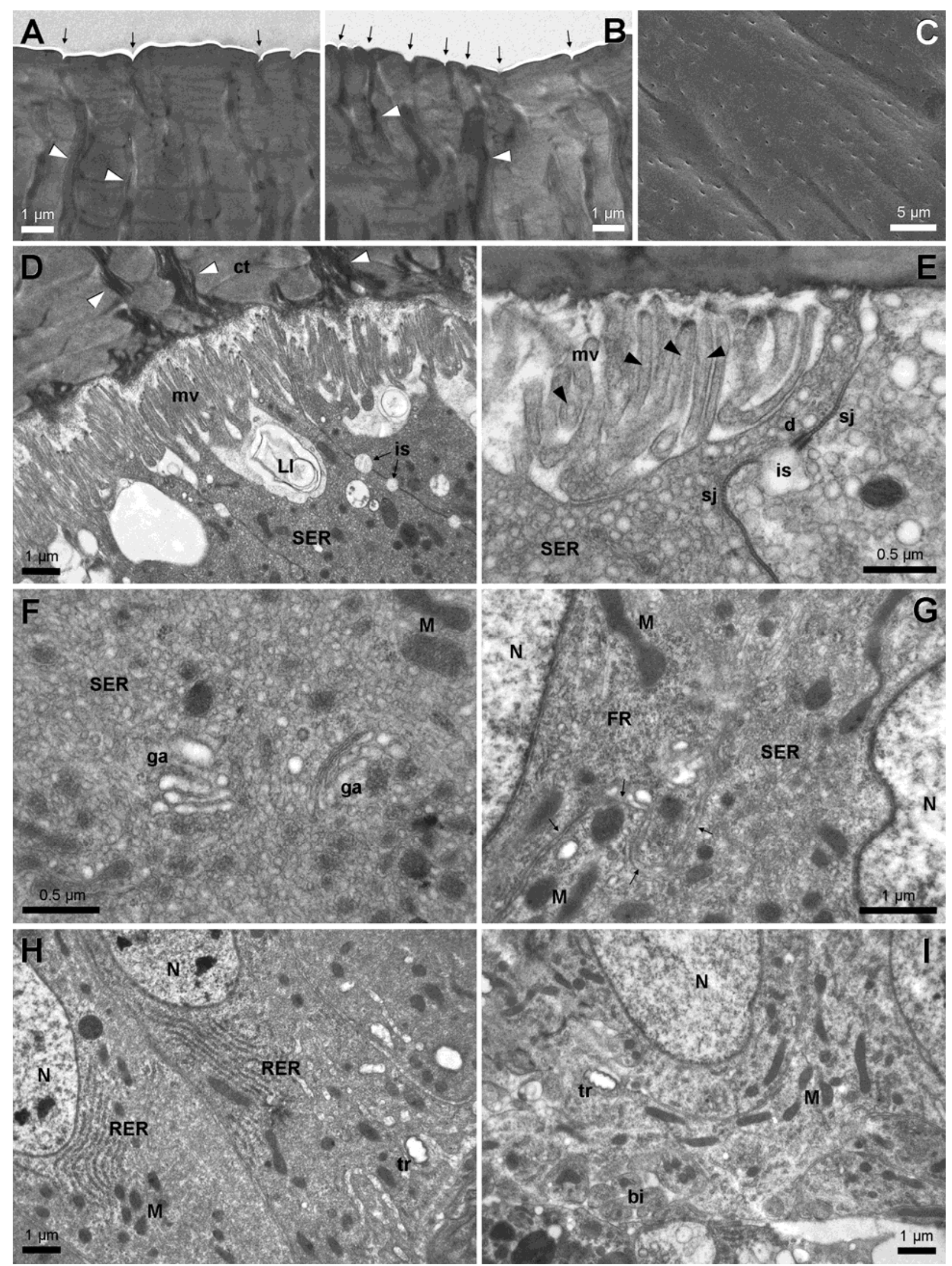

Fig. 3. Detail of upper mandibular surface (A) and of bottom of mandibular pit (B) in worker, showing transcuticular channels (white arrowheads) and their opening at the surface as small pores (arrows). C. High magnification scanning micrograph of the dorsal mandibular surface of a worker showing small slit-like openings. D,E: 
Ultrastructure of cuticle and apical cytoplasm in worker, showing irregular transcuticular channels (white arrowheads), apical microvilli (mv) and abundant smooth endoplasmic reticulum (SER). Note continuation of SER into core of microvilli (black arrowheads) and intercellular contacts that include desmosomes (d), widened intercellular spaces (is) and septate junctions (sj). F (worker) and G (queen): Ultrastructure of central cytoplasm with well-developed smooth endoplasmic reticulum (SER) and Golgi apparatus (ga). Note accumulation of free ribosomes (FR) near nucleus (N) and folded cell junction (arrows). H (worker) and I (queen): Ultrastructure of basal cell cytoplasm, with areas of granular endoplasmic reticulum (RER) below nuclei $(\mathrm{N})$, basal invaginations of cell membrane (bi) and tracheoles (tr) that penetrate between secretory cells. ct: cuticle, LI: lamellar inclusions, M: mitochondria. 